\title{
Adrenomedullin Does Not Contribute toward the Development of Abdominal Aortic Aneurysm in Mice
}

\author{
Sumiharu Sakamoto1, Toshihiro Tsuruda ${ }^{1}$, Kinta Hatakeyama ${ }^{2}$, Tatsuo Shimosawa ${ }^{3}$, \\ Yujiro Asada ${ }^{2}$, Kazuo Kitamura ${ }^{1}$ \\ ${ }^{1}$ Department of Internal Medicine, Circulatory and Body Fluid Regulation, Faculty of Medicine, University of \\ Miyazaki, Miyazaki, Japan \\ ${ }^{2}$ Department of Pathology, Faculty of Medicine, University of Miyazaki, Miyazaki, Japan \\ ${ }^{3}$ Department of Clinical Laboratory, Graduate School of Medicine, The University of Tokyo, Tokyo, Japan \\ Email: ${ }^{*}$ tsuruda@med.miyazaki-u.ac.jp
}

Received 5 March 2014; revised 9 April 2014; accepted 16 April 2014

Copyright (C) 2014 by authors and Scientific Research Publishing Inc.

This work is licensed under the Creative Commons Attribution International License (CC BY).

http://creativecommons.org/licenses/by/4.0/

(c) (i) Open Access

\begin{abstract}
Abdominal aortic aneurysm (AAA) develops based on advanced atherosclerosis; however, the underlying pathogenesis remains unknown. Adrenomedullin (AM) is widely expressed in various human and rodent tissues, and has been reported to protect blood vessels. We have previously reported that $A M$ is produced in mast cells of human AAA and that AM exhibited the antifibrotic activity of mast cell-derived AM on fibroblasts. In the present study, we investigated the role of AM in the development of AAA in 12-week-old male apolipoprotein (apo) $\mathrm{E}^{-/-}$mice bred with AM heterozygous, or its role when recombinant human (rh) AM was administrated to the apo: $\mathrm{E}^{-/-}$male mice, which was infused with $1000 \mathrm{ng} / \mathrm{kg} / \mathrm{min}$ of angiotensin II (Ang II) for 28 days. The incidence of the development of AAA in Ang II-infused apoE $\mathrm{E}^{-/-} \mathrm{AM}^{+/-}$mice did not change compared with that in apoE ${ }^{-/-}$mice $(33.3 \%$ vs. $47.4 \%, p=0.2333)$. In addition, rhAM administration had little effect on the incidence of the development of AAA formation (AM: $0 \mathrm{ng} / \mathrm{kg} / \mathrm{hr} 47.4 \% ; 300 \mathrm{ng} / \mathrm{kg} / \mathrm{hr} 36.4 \%$; $3000 \mathrm{ng} / \mathrm{kg} / \mathrm{hr} 27.3 \% ; p=0.2595$ ). In conclusion, this study suggests that AM does not contribute toward the development of AAA.
\end{abstract}

\section{Keywords}

Aneurysm, Angiotensin II, Aortic Rupture

\footnotetext{
*Corresponding author.
} 


\section{Introduction}

Abdominal aortic aneurysm (AAA) is a relatively common disorder among individuals who are $>60$ years of age [1]. AAA develops based on advanced atherosclerosis [2], and it is pathologically characterized by an enlarged aortic lumen accompanied by a degenerated medial layer [3]. Chronic inflammation is predominantly observed in the outer-media and adventitia of the aneurysm wall [4] [5], and immune and inflammatory responses have been suggested to contribute toward pathogenesis of AAA [2] [6] [7]. However, the underlying mechanism of AAA progression remains unclear. Currently, medical therapy to attenuate or regress the development of AAA is unavailable.

Adrenomedullin (AM) was originally isolated from human pheochromocytoma [8]. It is a 52-amino acid peptide containing an intramolecular disulfide bond that forms a ring-like structure of six residues. AM is widely distributed among various tissues and organs, including the heart and aorta [9]-[11]. AM decreases the blood pressure and it inhibits cellular proliferation in the heart and blood vessels [8] [12] [13]. In addition, AM attenuates both the oxidative stress and inflammatory responses [14] [15]. We reported that AM was produced in mast cells present in the outer media and adventitia of AAA in humans, and discussed its possible involvement in the development of AAA by decreasing collagen synthesis in vitro [11].

Lipoprotein disorders are suggested to modify the atherogenesis and increase the cardiovascular risk [16]. Apolipoprotein E (apoE) can clear the cholesterol-enriched lipoprotein, and plays a protective role against atherosclerosis [17]. Mice inactivating the gene exhibit a marked increase in plasma level of total cholesterol, accompanied by progression of atheromatous plaque [18] [19]. Furthermore, administration of angiotensin II (Ang II) to the mice is susceptible to develop the AAA formation [20].

On the basis of previous studies, we hypothesized that AM might be involved in the development of AAA. In the present study, we conducted two experiments to clarify the role of AM in the development of AAA. In the first method, we administered subcutaneous Ang II to $\mathrm{AM}^{+/-}$and $\mathrm{apoE}^{-/-}$double knockout (apoE $\mathrm{E}^{-/-} \mathrm{AM}^{+/-}$) mice. In the second, we administered recombinant human (rh)AM to Ang II-infused apo: ${ }^{-/-}$mice.

\section{Materials and Methods}

\subsection{License for Experiment}

This study was conducted in accordance with the Animal Welfare Act and with the approval of both the University of Miyazaki Institutional Animal Care and Use Committee (\#2007-541-5) and the University of Miyazaki Committee for Genetic Modification (\#151-3 and \#230). This investigation also conformed to the Guide for the Care and Use of Laboratory Animals published by the National Institutes of Health (NIH Publication No. 85-23, revised 1996).

\subsection{Mice}

Paired apoE $\mathrm{E}^{-/-}$mice (B6.129P2-Apoe ${ }^{\mathrm{tm} 1 \mathrm{Unc}} / \mathrm{J}$, background strain C57BL/6J) were purchased from Jackson Laboratory (Bar Harbor, ME, USA), and were bred at our institution. $\mathrm{AM}^{+/-}$mice were developed as previously reported [15]. ApoE ${ }^{-/-} \mathrm{AM}^{+-}$mice were bred at our institution. Mouse genotyping was performed using genomic DNA extracted from tail biopsies. Specific genotyping for the apo $\mathrm{E}^{-/-}$mice was performed by polymerase chain reaction (PCR: Gene Amp ${ }^{\circledR}$ PCR System 2700, Life Technology Japan, Tokyo, Japan) with the following primers: oIMR0180 (5'-GCCTAGCCGAGGGAGAGCCG-3') as the wild-type sense primer, oIMR0181 (5'-TGTGACTTGGGAGCTCTGCAGC-3') as the antisense wild-type primer and oIMR0182 (5'-GCCGCCCCGACTGCATCT-3') as the apoE mutant antisense primer (Jackson Laboratory). The PCR was performed in the following three phases: $94^{\circ} \mathrm{C}$ for $3 \mathrm{~min}$; 35 cycle of $95^{\circ} \mathrm{C}$ for $20 \mathrm{~s}, 68^{\circ} \mathrm{C}$ for $40 \mathrm{~s}$, and $72^{\circ} \mathrm{C}$ for 1 min; and $72^{\circ} \mathrm{C}$ for 7 min. A 245-base pair (bp) PCR fragment was generated from a mutated apoE locus, whereas a 155-bp PCR fragment was generated from the wild-type locus (Figure 1). Specific genotyping for the AM knockout mice was performed by PCR with the following primers: (5'-GGCTCCTTAAGTTGCGCA-3') as the sense primer and (5'-ACGTAGAAGAACTTATTAAACCGCA-3') as the antisense primer [15]. The PCR was performed in the following three phases: $94^{\circ} \mathrm{C}$ for $3 \mathrm{~min}$; 35 cycles of $95^{\circ} \mathrm{C}$ for $30 \mathrm{~s}, 63^{\circ} \mathrm{C}$ for $1 \mathrm{~min}$, and $72^{\circ} \mathrm{C}$ for $1 \mathrm{~min}$; and $72^{\circ} \mathrm{C}$ for $7 \mathrm{~min}$. A 380-bp PCR fragment was generated from a mutated AM locus, whereas a 300-bp PCR fragment was generated from the wild-type AM locus (Figure 1). 


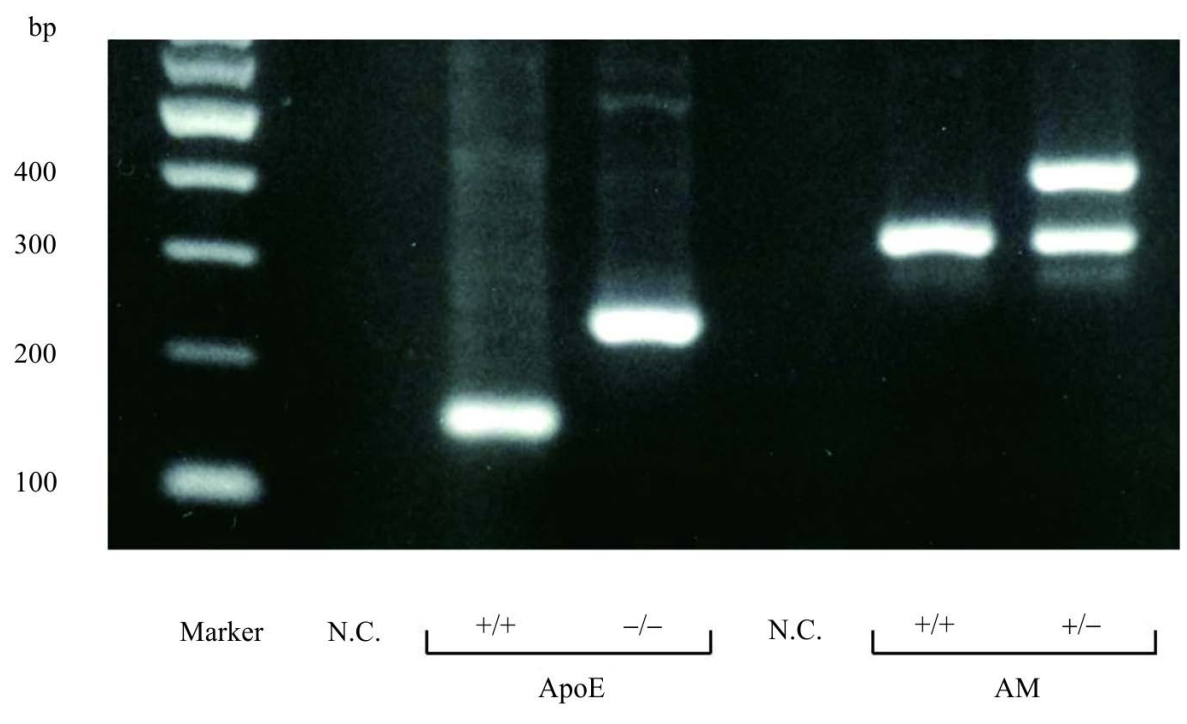

Figure 1. PCR amplification electrophoretogram of $a p o E^{+/+}$(155-bp), apoE $\mathrm{E}^{-/-}$(245-bp), $\mathrm{AM}^{+/+}$(300-bp) and $\mathrm{AM}^{+/}$(300- and 380-bp). bp, base pair. N.C. indicates negative control.

\subsection{Induction of AAA}

Mice were housed in a temperature- and light-controlled room $\left(25^{\circ} \mathrm{C} \pm 1^{\circ} \mathrm{C} ; 12 / 12\right.$-hour light/dark cycle) with free access to normal chow and water until the end of the experiment. At 12 weeks of age, male mice were anesthetized by intraperitoneal administration of 2,2,2-tribromoethanol (Avertin) at $200 \mathrm{mg} / \mathrm{kg}$, and osmotic mini-pumps (Alzet Model 1004; DURECT Co., Mountain View, CA, USA) were subcutaneously implanted.

Protocol 1: Osmotic mini-pump filled with either saline or Ang II (1000 ng/kg/min, Sigma Chemical Co., St. Louis, MO, USA) was implanted in apoE ${ }^{-/-}$mice and apoE ${ }^{-/-} \mathrm{AM}^{+/-}$mice for 28 days.

Protocol 2: Osmotic mini-pumps filled with either saline or Ang II (1000 ng/kg/min) in the presence or absence of rhAM (300 or $3000 \mathrm{ng} / \mathrm{kg} / \mathrm{hr}$ SHIONOGI \& CO., LTD., Osaka, Japan) were subcutaneously implanted into the apoE ${ }^{-/-}$mice for 28 days.

At the end of 28 days, the mice were anesthetized by intraperitoneal administration of $85 \mathrm{mg} / \mathrm{kg}$ pentobarbital sodium: their aortas were harvested and perfused with $4 \%$ paraformaldehyde.

\subsection{Blood Pressure and Heart Rate}

Tail-cuff blood pressure was recorded on day 28 using a noninvasive computerized tail-cuff system (BP98A Softron, Tokyo, Japan) while the animal was conscious. The mean values of blood pressure and heart rate were determined from at least three successful measurements after 2 days of training.

\subsection{Analysis and Quantification of AAA}

For quantifying the incidence of aneurysm, we defined an aneurysm as an increase in the external width of the suprarenal aorta by $50 \%$ or greater compared with aortas from saline-infused mice. The average diameter of the normal suprarenal aorta in control mice was $0.96 \mathrm{~mm}$. Therefore, as evidence of the development of an aneurysm, we set a threshold of $1.44 \mathrm{~mm}$. The diameter of the supra-renal aorta was measured by WinRoof software, version 5.6 (Mitani Co., Tokyo, Japan).

\subsection{Statistical Analysis}

All results are expressed as mean \pm standard error of the mean (SEM). The Mann-Whitney test was used for comparing continuous variables. Fisher's exact test was used for comparing categorical variables. Survival curves were estimated using the Kaplan-Meier method, and data were compared by the log-rank test. Tests were conducted using PRISM 5.01 (GraphPad Software, Inc., La Jolla, CA, USA). Differences were considered statistically significant when $p<0.05$. 


\section{Results}

\subsection{Systolic Blood Pressure, Heart Rate and Body Weight}

Table 1 shows that systolic blood pressure increased significantly $(p<0.05)$ in all mice infused with Ang II compared with those infused with saline. There was no significant difference in systolic blood pressure between $\mathrm{apoE}^{-/-}$and $\mathrm{apoE}^{-/-} \mathrm{AM}^{+/}$mice infused with Ang II. In addition, rhAM infusion (300 and $3000 \mathrm{ng} / \mathrm{kg} / \mathrm{hr}$ ) did not affect systolic blood pressure in Ang II-induced apoE ${ }^{-/-}$mice. There was no significant difference in heart rate and body weight among five groups.

\subsection{Mortality and Cause of Death}

The 28-day survival rate did not differ significantly among the five groups (log-rank test, $p=0.2735$ ) (Figure 2(a)), although Ang II-infused apoE ${ }^{-/-}$mice treated with $3000 \mathrm{ng} / \mathrm{kg} / \mathrm{h}$ of AM tended to have a high mortality rate and a high incidence of aortic rupture compared with the other groups (Figure 2(b)). The causes of death were as follows: pleural hemorrhage $(n=1)$ in apoE $^{-/-}$mice infused with Ang II; pleural hemorrhage $(n=1)$ and unknown cause $(\mathrm{n}=1)$ in $\mathrm{apoE}^{-/-} \mathrm{AM}^{+-}$mice infused with Ang II; pleural hemorrhage $(\mathrm{n}=2)$ and intra-abdominal hemorrhage $(\mathrm{n}=2)$ in Ang II-infused apoE ${ }^{-/-}$mice treated with $3000 \mathrm{ng} / \mathrm{kg} / \mathrm{h}$ of rhAM.

\subsection{Incidence of AAA}

Figure 2(c) shows the incidence of the development of AAA in mice that survived for 28 days. Ang II-infused apoE $^{-/-} \mathrm{AM}^{+/-}$mice and Ang II-infused apoE $\mathrm{E}^{-/-}$mice exhibited insignificant incidence of the development of AAA ( $p=0.2333$ ). In addition, development of AAA tended to decrease with rhAM infusion at 300 and 3000 $\mathrm{ng} / \mathrm{kg} / \mathrm{hr}$; however, the difference was not statistically significant $(p=0.2595)$.

\subsection{Size of Supra-Renal Aorta}

Figures 3(a)-(e) showed the representative pictures of suprarenal aorta in each group. As shown in Figure 3(f), the maximal diameter of the suprarenal aorta increased significantly $(p=0.0353)$ in Ang II-infused apoE ${ }^{-/-}$mice compared with those infused with saline. However, the suprarenal aortic size did not significantly change in either Ang II-infused apoE ${ }^{-/-} \mathrm{AM}^{+/-}$mice or upon administration of rhAM in Ang II-infused apoE ${ }^{-/-}$mice.

\section{Discussion}

This study was designed to evaluate the effect of AM on the development of AAA in two ways-through the use of a genetically altered AM gene; and by exogenous administration of rhAM to Ang II-infused AAA model in mice. Based on the anti-inflammatory, -atherosclerotic and -oxidative activities of AM [14] [15] [21], we postulated that AM would protect against AAA development and rupture. However, in this study, we found that AM had little effect on these phenomena.

There are several possible explanations for the lack of beneficial effects of AM on aneurysm development. First, the incidence of Ang II-induced AAA development in apoE ${ }^{-/-}$mice in this study was $47 \%$, and was lower than the incidence observed in previous studies (75\% to 100\%) [22]-[24]. Moreover the maximal diameter of the

\begin{tabular}{|c|c|c|c|c|c|}
\hline & $\mathbf{A p o E}^{-/-} \mathbf{A M}^{+/+}$ & $\mathbf{A p o E}^{-/-} \mathbf{A M}^{+/+}$ & $\mathbf{A p o E}^{-/-} \mathbf{A M}^{+/-}$ & $\mathbf{A p o E}^{-/-} \mathbf{A M}^{+/+}$ & $\mathbf{A p o E}^{-/-} \mathbf{A M}^{+/+}$ \\
\hline $\begin{array}{c}\text { Ang II } \\
1000 \mathrm{ng} / \mathrm{kg} / \mathrm{min}\end{array}$ & $(-)$ & $(+)$ & $(+)$ & $(+)$ & $(+)$ \\
\hline $\begin{array}{c}\text { rhAM } \\
\mathrm{ng} / \mathrm{kg} / \mathrm{hr}\end{array}$ & $\mathbf{0}$ & $\mathbf{0}$ & 0 & 300 & 3000 \\
\hline BW g & $28.4 \pm 0.3$ & $27.0 \pm 0.5(17)$ & $27.3 \pm 0.3(27)$ & $28.2 \pm 0.4(11)$ & $27.5 \pm 0.6(16)$ \\
\hline SBP mmHg & $91 \pm 1$ (4) & $123 \pm 3^{*}(17)$ & $124 \pm 3^{*}(27)$ & $126 \pm 7^{*}(11)$ & $125 \pm 6^{*}(16)$ \\
\hline $\mathbf{H R} / \mathrm{min}$ & $580 \pm 6(4)$ & $621 \pm 17(17)$ & $599 \pm 13(27)$ & $610 \pm 12(11)$ & $554 \pm 16(16)$ \\
\hline
\end{tabular}

Data are expressed as mean \pm SEM. Parentheses indicate the number of mice examined. ${ }^{*} p<0.05$ vs. apoE ${ }^{-/ /} \mathrm{AM}^{+/+}$with saline. rhAM, recombinant human adrenomedullin; BW, body weight; SBP, systolic blood pressure; HR, heart rate; Ang II, angiotensin II. 
a

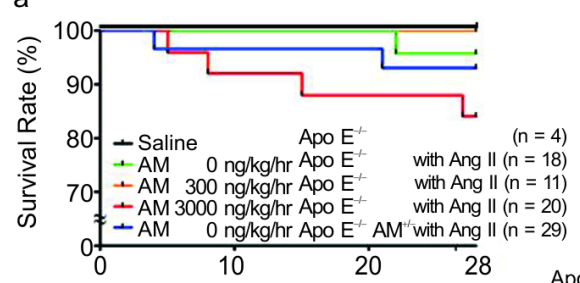

C

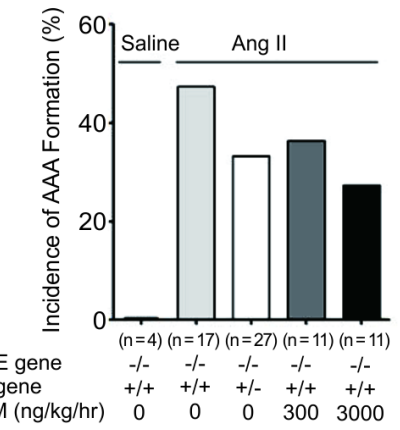

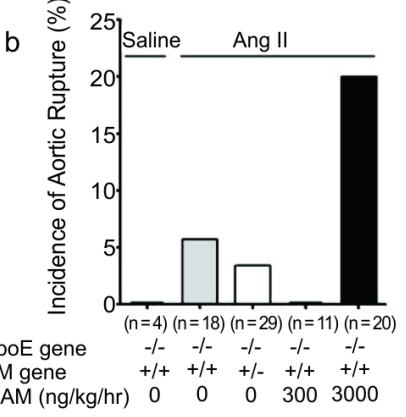

$\mathrm{rhAM}(\mathrm{ng} / \mathrm{kg} / \mathrm{hr}) \quad 0 \quad 0 \quad 0 \quad 3003000$

Figure 2. (a) Survival rates of: apoE ${ }^{-/-}$mice infused with saline $(\mathrm{n}=4$, black) or $1000 \mathrm{ng} / \mathrm{kg} / \mathrm{min}$ of Ang II ( $\mathrm{n}=18$, green); $\mathrm{apoE}^{-/-} \mathrm{AM}^{+/-}$mice infused with $1000 \mathrm{ng} / \mathrm{kg} / \mathrm{min}$ of Ang II ( $=29$, blue); and $\mathrm{apoE}^{-/-}$mice infused with $1000 \mathrm{ng} / \mathrm{kg} / \mathrm{min}$ of Ang II and administered either $300 \mathrm{ng} / \mathrm{kg} / \mathrm{h}$ rhAM ( $=11$, orange) or $3000 \mathrm{ng} / \mathrm{kg} / \mathrm{h}$ rhAM ( $\mathrm{n}=20$, red). Incidence of aortic rupture (b) and development of AAA in mice that survived for 28 days (c) in apoE $\mathrm{E}^{-}$ mice infused with either saline or $1000 \mathrm{ng} / \mathrm{kg} / \mathrm{min}$ of Ang II; apoE $\mathrm{E}^{-/-} \mathrm{AM}^{+/-}$ mice infused with $1000 \mathrm{ng} / \mathrm{kg} / \mathrm{min}$ of Ang II; and apoE $\mathrm{E}^{-/-}$mice infused with $1000 \mathrm{ng} / \mathrm{kg} / \mathrm{min}$ of Ang II and administered either 300 or $3000 \mathrm{ng} / \mathrm{kg} / \mathrm{hr}$ of rhAM. Parenthesis indicates the number of mice examined.
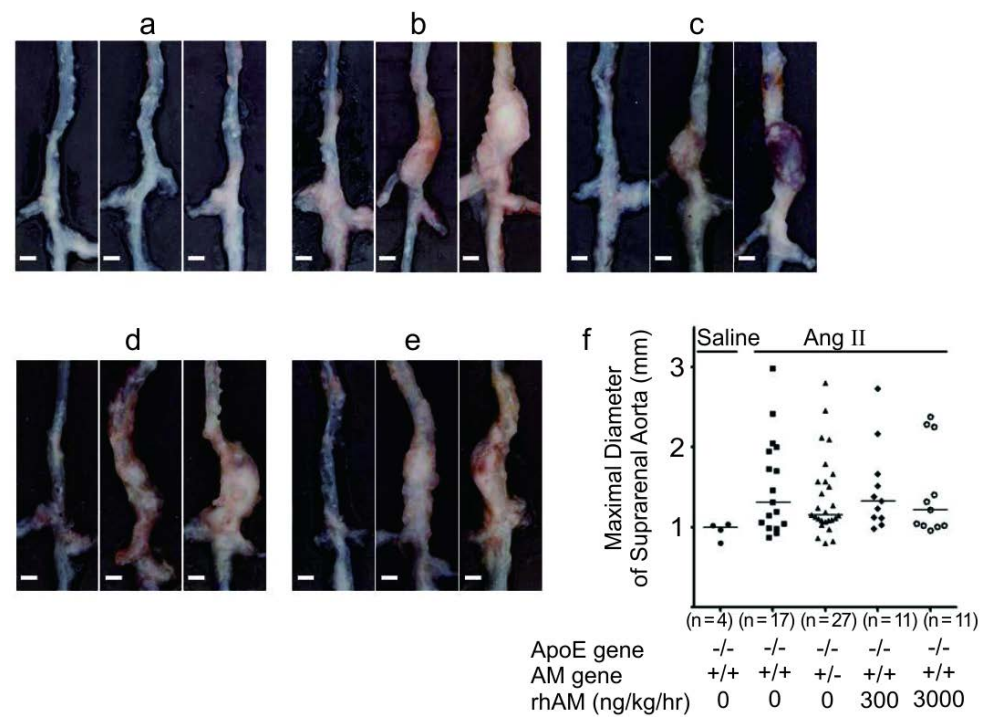

Figure 3. Representative pictures (a)-(e) and maximal diameter (f) of the suprarenal aorta in apo $\mathrm{E}^{-/-}$mice infused with either saline (a) or $1000 \mathrm{ng} / \mathrm{kg} / \mathrm{min}$ of Ang II (b); apoE $\mathrm{E}^{-/-} \mathrm{AM}^{+/}$mice infused with $1000 \mathrm{ng} / \mathrm{kg} / \mathrm{min}$ of Ang II (c); and $\mathrm{apoE}^{-\gamma-}$ mice infused with $1000 \mathrm{ng} / \mathrm{kg} / \mathrm{min}$ of Ang II and administered either 300 (d) or $3000 \mathrm{ng} / \mathrm{kg} / \mathrm{hr}$ (e) of rhAM. Parenthesis indicates the number of mice examined. Scale bar, $1 \mathrm{~mm}$. Bars in Figure 3(f) indicate the median. 
supra-renal aorta was widely distributed between 0.8 and $2.8 \mathrm{~mm}$. These differences may have resulted from our use of younger mice that were fed normal chow. Secondly, we used heterozygous AM mice but not homozygous mice which are lethal due to the impairment of angiogenesis and lymph-angiogenesis during the embryonic development [25] [26]. Heterozygous AM mice exhibit AM levels in organs and plasma that are half the levels present in wild types [15]. Thus, we might have been unable to observe the full biological inactivity of AM in $\mathrm{AM}^{+/-}$mice. We attempted to overcome this shortcoming by administering rhAM to Ang II-infused apoE ${ }^{-/}$ mice. We chose to administer $300 \mathrm{ng} / \mathrm{kg} / \mathrm{hr}$ of rhAM based on the report by Pan et al. [21], which showed that AM administration ameliorated vascular atherosclerotic lesions in rodents. We increased the dose up to 3000 $\mathrm{ng} / \mathrm{kg} / \mathrm{hr}$ and found that the dose rather increased the mortality. We speculate that the anti-fibrotic action of AM [11] [27] might have led to outcomes.

\section{Conclusion}

This study suggests that AM is unlikely to be involved in the pathogenesis of AAA development.

\section{Acknowledgements}

This study was supported by Grants-in-Aid for Scientific Research (B) (K. K., 22390161) from the Ministry of Education, Culture, Sport, Science and Technology, Japan and in part by a Research Grant for Cardiovascular Diseases (20C-3, principal investigator: Toshiyuki Miyata, co-investigator: K. K.) from the Ministry of Health, Labour and Welfare of Japan. We are greatly indebted to Ms. Ritsuko Sotomura, Yoko Sekita and Mariko Tokashiki for their expert technical assistance. The authors would like to thank Enago (www.enago.jp) for the English language review.

\section{References}

[1] Brady, A.R., Fowkes, F.G., Thompson, S.G. and Powell, J.T. (2001) Aortic Aneurysm Diameter and Risk of Cardiovascular Mortality. Arteriosclerosis, Thrombosis, and Vascular Biology, 21, 1203-1207. http://dx.doi.org/10.1161/hq0701.091999

[2] Shimizu, K., Mitchell, R.N. and Libby, P. (2006) Inflammation and Cellular Immune Responses in Abdominal Aortic Aneurysms. Arteriosclerosis, Thrombosis, and Vascular Biology, 26, 987-994. http://dx.doi.org/10.1161/01.ATV.0000214999.12921.4f

[3] Lopez-Candales, A., Holmes, D.R., Liao, S., Scott, M.J., Wickline, S.A. and Thompson, R.W. (1997) Decreased Vascular Smooth Muscle Cell Density in Medial Degeneration of Human Abdominal Aortic Aneurysms. American Journal of Pathology, 150, 993-1007.

[4] Bobryshev, Y.V. and Lord, R.S. (2001) Vascular-Associated Lymphoid Tissue (VALT) Involvement in Aortic Aneurysm. Atherosclerosis, 154, 15-21. http://dx.doi.org/10.1016/S0021-9150(00)00441-X

[5] Tsuruda, T., Kato, J., Hatakeyama, K., Kojima, K., Yano, M., Yano, Y., Nakamura, K., Nakamura-Uchiyama, F., Matsushima, Y., Imamura, T., Onitsuka, T., Asada, Y., Nawa, Y., Eto, T. and Kitamura, K. (2008) Adventitial Mast Cells Contribute to Pathogenesis in the Progression of Abdominal Aortic Aneurysm. Circulation Research, 102, 1368-1377. http://dx.doi.org/10.1161/CIRCRESAHA.108.173682

[6] Freestone, T., Turner, R.J., Coady, A., Higman, D.J., Greenhalgh, R.M. and Powell, J.T. (1995) Inflammation and Matrix Metalloproteinases in the Enlarging Abdominal Aortic Aneurysm. Arteriosclerosis, Thrombosis, and Vascular Biology, 15, 1145-1151. http://dx.doi.org/10.1161/01.ATV.15.8.1145

[7] Halpern, V.J., Nackman, G.B., Gandhi, R.H., Irizarry, E., Scholes, J.V., Ramey, W.G. and Tilson, M.D. (1994) The Elastase Infusion Model of Experimental Aortic Aneurysms: Synchrony of Induction of Endogenous Proteinases with Matrix Destruction and Inflammatory Cell Response. Journal of Vascular Surgery, 20, 51-60.

http://dx.doi.org/10.1016/0741-5214(94)90175-9

[8] Kitamura, K., Kangawa, K., Kawamoto, M., Ichiki, Y., Nakamura, S., Matsuo, H. and Eto, T. (1993) Adrenomedullin: A Novel Hypotensive Peptide Isolated from Human Pheochromocytoma. Biochemical and Biophysical Research Communications, 192, 553-560. http://dx.doi.org/10.1006/bbrc.1993.1451

[9] Asada, Y., Hara, S., Marutsuka, K., Kitamura, K., Tsuji, T., Sakata, J., Sato, Y., Kisanuki, A., Eto, T. and Sumiyoshi, A. (1999) Novel Distribution of Adrenomedullin-Immunoreactive Cells in Human Tissues. Histochemistry and Cell Biology, 112, 185-191. http://dx.doi.org/10.1007/s004180050406

[10] Kitamura, K., Sakata, J., Kangawa, K., Kojima, M., Matsuo, H. and Eto, T. (1993) Cloning and Characterization of cDNA Encoding a Precursor for Human Adrenomedullin. Biochemical and Biophysical Research Communications, 
194, 720-725. http://dx.doi.org/10.1006/bbrc.1993.1881

[11] Tsuruda, T., Kato, J., Hatakeyama, K., Yamashita, A., Nakamura, K., Imamura, T., Kitamura, K., Onitsuka, T., Asada, Y. and Eto, T. (2006) Adrenomedullin in Mast Cells of Abdominal Aortic Aneurysm. Cardiovascular Research, 70, 158-164. http://dx.doi.org/10.1016/j.cardiores.2006.02.003

[12] Kano, H., Kohno, M., Yasunari, K., Yokokawa, K., Horio, T., Ikeda, M., Minami, M., Hanehira, T., Takeda, T. and Yoshikawa, J. (1996) Adrenomedullin as a Novel Antiproliferative Factor of Vascular Smooth Muscle Cells. Journal of Hypertension, 14, 209-213. http://dx.doi.org/10.1097/00004872-199602000-00009

[13] Tsuruda, T., Kato, J., Kitamura, K., Kawamoto, M., Kuwasako, K., Imamura, T., Koiwaya, Y., Tsuji, T., Kangawa, K. and Eto, T. (1999) An Autocrine or a Paracrine Role of Adrenomedullin in Modulating Cardiac Fibroblast Growth. Cardiovascular Research, 43, 958-967. http://dx.doi.org/10.1016/S0008-6363(99)00122-4

[14] Kawai, J., Ando, K., Tojo, A., Shimosawa, T., Takahashi, K., Onozato, M.L., Yamasaki, M., Ogita, T., Nakaoka, T. and Fujita, T. (2004) Endogenous Adrenomedullin Protects against Vascular Response to Injury in Mice. Circulation, 109, 1147-1153. http://dx.doi.org/10.1161/01.CIR.0000117231.40057.6D

[15] Shimosawa, T., Shibagaki, Y., Ishibashi, K., Kitamura, K., Kangawa, K., Kato, S., Ando, K. and Fujita, T. (2002) Adrenomedullin, an Endogenous Peptide, Counteracts Cardiovascular Damage. Circulation, 105, 106-111. http://dx.doi.org/10.1161/hc0102.101399

[16] Genest, J. (2003) Lipoprotein Disorders and Cardiovascular Risk. Journal of Inherited Metabolic Disease, 26, $267-287$. http://dx.doi.org/10.1023/A:1024449603891

[17] Mahley, R.W. (1988) Apolipoprotein E: Cholesterol Transport Protein with Expanding Role in Cell Biology. Science, 240, 622-630. http://dx.doi.org/10.1126/science.3283935

[18] Plump, A.S., Smith, J.D., Hayek, T., Aalto-Setala, K., Walsh, A., Verstuyft, J.G., Rubin, E.M. and Breslow, J.L. (1992) Severe Hypercholesterolemia and Atherosclerosis in Apolipoprotein E-Deficient Mice Created by Homologous Recombination in ES Cells. Cell, 71, 343-353. http://dx.doi.org/10.1016/0092-8674(92)90362-G

[19] Nakashima, Y., Plump, A.S., Raines, E.W., Breslow, J.L. and Ross, R. (1994) ApoE-Deficient Mice Develop Lesions of All Phases of Atherosclerosis throughout the Arterial Tree. Arteriosclerosis and Thrombosis, 14, 133-140. http://dx.doi.org/10.1161/01.ATV.14.1.133

[20] Daugherty, A., Manning, M.W. and Cassis, L.A. (2000) Angiotensin II Promotes Atherosclerotic Lesions and Aneurysms in Apolipoprotein E-Deficient Mice. Journal of Clinical Investigation, 105, 1605-1612. http://dx.doi.org/10.1172/JCI7818

[21] Pan, C.S., Zhang, J., Yu, F., Teng, X., Cao, C.Q., Wu, W., Tang, C.S. and Qi, Y.F. (2010) Adrenomedullin Ameliorates the Development of Atherosclerosis in apoE $^{-/-}$Mice. Peptides, 31, 1150-1158. http://dx.doi.org/10.1016/j.peptides.2010.03.005

[22] Deng, G.G., Martin-McNulty, B., Sukovich, D.A., Freay, A., Halks-Miller, M., Thinnes, T., Loskutoff, D.J., Carmeliet, P., Dole, W.P. and Wang, Y.X. (2003) Urokinase-Type Plasminogen Activator Plays a Critical Role in Angiotensin II-Induced Abdominal Aortic Aneurysm. Circulation Research, 92, 510-517. http://dx.doi.org/10.1161/01.RES.0000061571.49375.E1

[23] Wang, Y.X., Martin-McNulty, B., da Cunha, V., Vincelette, J., Lu, X., Feng, Q., Halks-Miller, M., Mahmoudi, M., Schroeder, M., Subramanyam, B., Tseng, J.L., Deng, G.D., Schirm, S., Johns, A., Kauser, K., Dole, W.P. and Light, D.R. (2005) Fasudil, a Rho-Kinase Inhibitor, Attenuates Angiotensin II-Induced Abdominal Aortic Aneurysm in Apolipoprotein E-Deficient Mice by Inhibiting Apoptosis and Proteolysis. Circulation, 111, 2219-2226. http://dx.doi.org/10.1161/01.CIR.0000163544.17221.BE

[24] Yamanouchi, D., Morgan, S., Kato, K., Lengfeld, J., Zhang, F. and Liu, B. (2010) Effects of Caspase Inhibitor on Angiotensin II-Induced Abdominal Aortic Aneurysm in Apolipoprotein E-Deficient Mice. Arteriosclerosis, Thrombosis, and Vascular Biology, 30, 702-707. http://dx.doi.org/10.1161/ATVBAHA.109.200527

[25] Fritz-Six, K.L., Dunworth, W.P., Li, M. and Caron, K.M. (2008) Adrenomedullin Signaling Is Necessary for Murine Lymphatic Vascular Development. Journal of Clinical Investigation, 118, 40-50. http://dx.doi.org/10.1172/JCI33302

[26] Shindo, T., Kurihara, Y., Nishimatsu, H., Moriyama, N., Kakoki, M., Wang, Y., Imai, Y., Ebihara, A., Kuwaki, T., Ju, K.H., Minamino, N., Kangawa, K., Ishikawa, T., Fukuda, M., Akimoto, Y., Kawakami, H., Imai, T., Morita, H., Yazaki, Y., Nagai, R., Hirata, Y. and Kurihara, H. (2001) Vascular Abnormalities and Elevated Blood Pressure in Mice Lacking Adrenomedullin Gene. Circulation, 104, 1964-1971. http://dx.doi.org/10.1161/hc4101.097111

[27] Tsuruda, T., Kato, J., Cao, Y.N., Hatakeyama, K., Masuyama, H., Imamura, T., Kitamura, K., Asada, Y. and Eto, T. (2004) Adrenomedullin Induces Matrix Metalloproteinase-2 Activity in Rat Aortic Adventitial Fibroblasts. Biochemical and Biophysical Research Communications, 325, 80-84. http://dx.doi.org/10.1016/j.bbrc.2004.10.014 


\section{Abbreviations}

AAA: abdominal aortic aneurysm;

ApoE: apolipoprotein E;

AM: adrenomedullin;

rhAM: recombnant human adrenomedullin;

Ang II: angiotensin II;

BW: body weight;

SBP: systolic blood pressure;

HR: heart rate. 